\title{
Identifying the Gaps in Students' Understanding of Manometer Reading
}

\section{Sarisavinarinawatie Shahrani Muhammad Leong ${ }^{1}$}

JSHQ Perera ${ }^{2}$

\author{
Masitah Shahrill2* \\ ${ }^{1}$ Maktab Sains Paduka Seri Begawan Sultan, Ministry of Education, Brunei Darussalam \\ 2Sultan Hassanal Bolkiah Institute of Education, Universiti Brunei Darussalam, Brunei Darussalam \\ *Email: masitah.shahrill@ubd.edu.bn
}

\author{
Doi:10.5901/mjss.2015.v6n4s1p27
}

\begin{abstract}
Physics, widely regarded as a difficult subject, is also abstract in nature whereby most of its concepts are intangible and hard to imagine. For instance, the concept of pressure, although it is a difficult concept to learn, it is also an important topic to master. Pressure not only appears in physics but also in other scientific fields such as in chemistry as one of the physical changes in the rate of change of reactions, and in biology or medicine involving blood pressure. In this study, students' understanding on the topic of pressure will be reported. Specifically, in identifying the students' misconceptions on manometer reading. A manometer is an instrument that uses a U-tube containing a liquid (either mercury or water) to measure gas pressure. From the interviews conducted with eleven Year 9 students, two main misconceptions were identified. The first misconception was on the existence of air pressure. The students failed to recognise its presence, as the effects of air pressure are often not obvious and undetectable. Additionally, two students on two separate interview occasions had referred to air pressure as vacuum. Another misconception was mistakenly taking the high liquid level of a manometer column as high pressure acting on that side and vice versa. This misconception is caused by again failing to comprehend that air and also gas pressure can cause liquid levels to change. Identifying these misconceptions will indeed assist Physics secondary school teachers to confront the issues relating to the difficulty concerning the pressure concept.
\end{abstract}

Keywords: physics; misconceptions; pressure concept; secondary school

\section{Introduction}

Physics is widely regarded as a difficult subject. For Ornek, Robinson and Haugan (2008), they found that students find physics difficult because they have to contend with different representations such as experiments, formulas and calculations, graphs, and conceptual explanations at the same time. Moreover, they have to make transformations among them. For example, students need to be able to transfer from graphical representations to mathematical representations. In addition, physics is an abstract subject whereby most of its concepts are intangible and hard to imagine.

One such concept is pressure. Pressure is a difficult concept to learn, however, it is an important topic to master. Lack of understanding on this topic can affect student learning in related topics. This is due to the fact that pressure is not only looked at in physics but also in other fields such as in chemistry as one of the physical changes in the rate of change of reactions, and in biology or medicine that is involving blood pressure. In addition, pressure forms the basis of understanding topics such as the internal structure of the earth, weather cycles, rock formation, Bernoulli's principle and plate tectonics. The absence of true understanding of this topic will also give rise to misconceptions. According to Hanuscin (n.d.) possessing misconceptions can have serious impacts on learning. Similarly, Thompson (2006) reasoned in the same way that learning in science can be considered to be a sequential process, so can the development of misconceptions. So once a misconception has been acquired it may be carried on and built upon further.

The purpose of this study is to identify the gaps of students' understanding of pressure, generally, and manometer reading specifically, and if there exists any misconceptions. A manometer is an instrument that uses a U-tube containing a liquid (either mercury or water) to measure gas pressure. 


\section{Review of the Literature}

\subsection{Students' understanding of pressure}

Pressure topic addressed in this study, presents a few problems to students. As outlined by Pathare and Pradhan (2011), the tendency to replace the complicated concept of pressure with simpler ones is common. Students often mistake force for pressure and they picture pressure as forceful and one-dimensional, as opposed to a state that is ambient and multidirectional (Smith, Carey, \& Wiser, 1985; Smith, Snir, \& Grosslight, 1992; deBerg, 1995; Smith, Maclin, Grosslight, \& Davis, 1997; Pathare \& Pradhan, 2011).

However, the confusions between force and pressure were not seen in our research study. What was discovered when investigating the possible causes for the struggle on manometer reading was the 'nonobvious causes and effects' of pressure. This was further elaborated by a number of studies (Resnick, 1996; Chi, 2000; Perkins \& Grotzer, 2000; Grotzer, 2004), whereby due to the nonobvious nature of pressure, there is a tendency to substitute active causal agents for passive ones. Hence, it was discovered in the research conducted that students perceive pressure as non-existent or vacuum as it cannot be seen.

It was also stated that when more complex models were considered to explain scientific phenomena, "the nonobvious agents in play require appropriate recognition" (Basca \& Grotzer, 2001, p. 5). This lack of recognition of air pressure persists in students and laypersons today, as was experienced by the research sample. Tyler (1998) found that students in various age groups failed to recognise air pressure while completing science activities focused on air pressure.

\subsection{Misconceptions}

There are many researches done with regards to misconceptions in science (Martin, Sexton \& Gerlovich, 2002; Mazur, 1997; Maier, 2004; Thompson, 2006) and most of them pointed out that what we teach and what students actually learn can be remarkably different. It turns out that many students are still holding the same misconceptions that they had prior to teaching and despite being able to solve advanced problems, students often fail to comprehend the most basic concepts. Misconception or 'alternate conception' is part of the "student's private knowledge that is strictly speaking not completely consensual by scientific standards, though it may make sense to the student himself" (Zirbel, 2006, p. 5). According to Sarwadi and Shahrill (2014), teachers should have the ability to identify the misconception, and subsequently prescribe appropriate instructional strategies so that diagnosis is done continuously throughout the learning process. In this current study, we investigated using the two tier MCQs; that is not only the wrong concepts the students possess but also the reasoning behind the misconceptions.

Indeed, educators would want their students to not only follow the arguments presented in class but also to think critically about what was said. In contrast to passive listening, thinking is hard work, and unfortunately many students are reluctant to deeply think through a problem. Although deeply thinking through problems will in the end be more rewarding, it initially might result in confusion. However, the initial state of confusion or disequilibrium is unavoidable in order to jump start the process of equilibrium (Damasio, 1999; Spitzer, 2002; LeDoux, 2003). Hence, a strategy was adopted to systematically examine the sample's alternate conception in order to provide appropriate treatment for conceptual change.

\subsection{Conceptual change}

The ultimate purpose of this research is to achieve conceptual change that not only confronts problems concerning teaching strategies but it also tackles misconceptions the students possess. According to Hewson (1992), when taking into account conceptual change "it is helpful to recognise the word change" (p. 23). Change here in this context does not strictly mean 'modify' or 'transform' completely as described by the Little Oxford English Dictionary (2006). Change as described by Hewson and Hewson (2006) is either entirely or partly 'altered' or 'exchanged' and this is consistent with what this strategy is trying to achieve and it suits the purpose of this study; that is promoting learning that changes an existing misconception or incorrect ideas of pressure concepts. Similar research done by Cil and Cepni (2012), in which although the students' conceptions were not entirely in line with the scientific explanation, however, there were major shift in understandings. This study focused on the shift or restructuring of existing knowledge and beliefs that distinguishes conceptual change from other types of learning. Learning for conceptual change is not merely accumulating new facts or learning new skills. In conceptual change, an existing conception is fundamentally changed or even replaced and 
becomes the conceptual framework that students use to solve problems, explain phenomena and function in their world.

As was mentioned earlier, students' preconceptions are resistant to change and this is because students have relied on these existing notions to understand and function in their world, they may not easily discard their ideas and adopt a new way of thinking. Thus, simply presenting a new concept or telling the students that their views are inaccurate will not result in conceptual change. Teaching for conceptual change requires a constructivist approach in which students take an active role in reorganizing their knowledge. Cognitive conflict strategies, derived from a Piagetian constructivist view of learning, are effective tools in teaching for conceptual change (Duit, 2003). These strategies involve creating situations where students' existing conceptions about particular topics are made clear and then directly challenged in order to create a state of cognitive conflict or disequilibrium.

Cognitive conflict has been used as the basis for developing a number of models and strategies for teaching for conceptual change. Among these are the Conceptual Change Model (Posner, Strike, Hewson, \& Gertzog, 1982), the Conceptual Change Teaching Strategy (Nussbaum \& Novick, 1982), the Generative Learning Model (Cosgrove \& Osborne, 1985), the Ideational Confrontation Model (Champagne, Gunstone, \& Klopfer, 1985), and an instructional strategy using anomalous data (Chinn \& Brewer, 1993). Although these models suggest different methods and techniques, they all share a similar structure.

What was similarly suggested by the previous researches was that conceptual change might occur in several different ways, such as the addition of new conceptions, reorganisation of current conceptions, and a rejection of conceptions. An important instructional aspect of the different models proposed was that students must be dissatisfied with their existing conception, the new conception must be intelligible, plausible and it must be fruitful. For our study, we introduced a new concept so that students are unable to reconcile the new concept with current knowledge and experience. Then experiences and information were provided that helped students make sense of the new conception.

\section{Methodology}

\subsection{Sample}

The collection of data was in two secondary schools in Brunei Darussalam. In School A, nine students from three Year 9 classes, and in School B, three students from one Year 9 class were initially selected for the interview data. The students' age ranged between 12 to 14 years old. All the students in the sample were following the 2-years of upper secondary programme and they will take their General Cambridge Education Ordinary Level or also known as the GCE O Level examinations at the end of Year 10.

\subsection{Instrumentations}

The design of the study follows the qualitative research design. However, the results and analysis of the interviews reported here were taken from a larger study involving lesson study cycles to improve the students' conceptions of pressure. The quantitative data from the larger study was collected by using suitable pre-, post, delayed post- and confirmatory-test instruments which consisted of questions intended at diagnosing the misconceptions as well as conceptual understanding of the students involved. The qualitative data were elicited from the interviews and video recordings. Hence the qualitative results reported here in this paper would only be from the analyses of the students' interviews.

Individual student interviews were organised after every post-test that is before the commencement of the next cycle. A few students were selected, not more than three, from each class and the selection was based on the incorrect answers and justifications they gave during the pre- and post-test. The interviews were done to collect in-depth data on their views regarding specific incorrect responses given. Further explanation and elaboration were also asked in order to identify any specific difficulties faced while answering the questions.

\subsection{Students' interview analysis}

Initially, three students from each class were intended to do the interviews after each cycle, however, one student from Year $9 \mathrm{C}$ was absent on the interview day. Hence, a total of 11 interviews were conducted to collect in-depth data on the students' understandings and difficulties when doing the post-test questions. The focus of the interview was directed on Items 1, 2 and 3 of the post-test questions in Tables 1, 2 and 3 respectively. The interviews were done according to the Interview Questions Protocol given in Figure 1. 
Table 1. Item 1 from the post-test questions for the focus of the interview

\begin{tabular}{|l|l|}
\hline \multicolumn{1}{|c|}{ Item 1 } & \multicolumn{1}{c|}{ Objectives } \\
\hline $\begin{array}{l}1 . \text { a) The diagram shows the level } \mathrm{X} \text { and } \mathrm{Y} \text { in a liquid manometer } \\
\text { when the gas tap is opened. }\end{array}$ & $\begin{array}{l}- \text { To investigate students' ability to measure } \\
\text { pressure of gases using manometers, find } \\
\text { out whether students know the correct } \\
\text { height difference of a manometer; given a } \\
\text { diagram, which is labelled differently from } \\
\text { the notes. }\end{array}$ \\
$\begin{array}{l}\text { What is the pressure of the gas in the cylinder? } \\
\text { A. } 18 \mathrm{~cm} \text { of liquid below atmospheric pressure } \\
\text { pressure in relation to the gas pressure } \\
\text { and in turn to recognise the existence of } \\
\text { atmospheric pressure. }\end{array}$ \\
$\begin{array}{l}\text { C. } 9 \mathrm{~cm} \text { of liquid below atmospheric pressure } \\
\text { D. } 18 \mathrm{~cm} \text { liquid above atmospheric pressure liquid above atmospheric pressure }\end{array}$ & \\
b) Explain the reason for your answer : & \\
\hline
\end{tabular}

Table 2. Item 2 from the post-test questions for the focus of the interview

\begin{tabular}{|l|l|}
\multicolumn{1}{|c|}{ Item 2 } & \multicolumn{1}{c|}{ Objectives } \\
\hline $\begin{array}{l}\text { 2. a) The diagram shows the water levels in a water manometer } \\
\text { used to measure the pressure of a gas supply. }\end{array}$ & $\begin{array}{l}\text { To investigate students' ability to measure } \\
\text { pressure of gases using manometers and } \\
\text { find out whether students know the correct } \\
\text { height difference of a manometer (given a } \\
\text { diagram which is labelled differently from the } \\
\text { notes and ltem 1). }\end{array}$ \\
How much greater than the atmospheric pressure is the \\
pressure of the gas supply? \\
A. $\quad 2 \mathrm{~cm}$ of water \\
B. $5 \mathrm{~cm}$ of water \\
C. $\quad 10 \mathrm{~cm}$ of water \\
D. $12 \mathrm{~cm}$ of water \\
b) Explain the reason for your answer:
\end{tabular}

Table 3. Item 3 from the post-test questions for the focus of the interview

\begin{tabular}{|l|l|}
\hline Item 3 & Objectives \\
in $\mathrm{cm}$ water. & $\begin{array}{l}\text { To investigate students' ability to measure } \\
\text { pressure of gases using manometers and } \\
\text { find out whether students know the correct } \\
\text { height difference of a manometer (given a } \\
\text { diagram which is labelled differently from the } \\
\text { notes and item 2). }\end{array}$ \\
What is the pressure of the gas? & \\
A. $8 \mathrm{~cm}$ of water more than atmospheric pressure \\
B. $12 \mathrm{~cm}$ of water more than atmospheric pressure \\
C. $8 \mathrm{~cm}$ of water less than atmospheric pressure \\
D. $12 \mathrm{~cm}$ of water less than atmospheric pressure & \\
b) Explain the reason for your answer: & \\
\hline
\end{tabular}




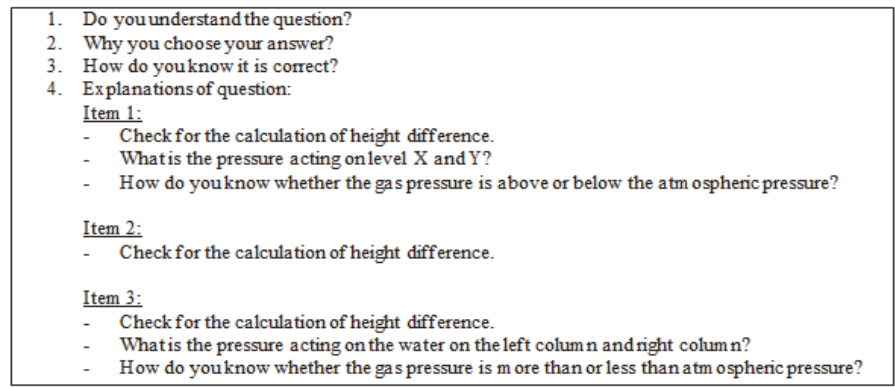

Figure 1. Interview Questions Protocol (For Items 1, 2 and 3)

\section{Results and Discussions}

From the interviews conducted with the eleven Year 9 students, two main misconceptions on manometer reading were identified. The first misconception was on the existence of air pressure. The students failed to recognise its presence, as the effects of air pressure are often not obvious and undetectable. According to Kariotoglou and Psillos (1993) students are oblivious to the presence of air pressure as the effects of air pressure are often not obvious and undetectable.

Table 4. Interview transcriptions for Items 1, 2 and 3 for the three Year 9 students

\begin{tabular}{|c|c|c|c|}
\hline No. & Item 1 & Item 2 & Item 3 \\
\hline $\begin{array}{l}\overleftarrow{\Phi} \\
\text { ஸें } \\
\text { ஸे }\end{array}$ & $\begin{array}{l}\text { I understand the question. } \\
\text { I choose A because I calculate height like } \mathrm{u} \\
\text { taught me. } \\
\text { It is below because level } \mathrm{X} \text { is lower. }\end{array}$ & $\begin{array}{l}\text { I understand the question. } \\
15 \text { minus } 5 \text { only. }\end{array}$ & $\begin{array}{l}\text { I understand the question. I must minus } \\
\text { and take the height. } \\
\text { I was confused like the last time about } \\
\text { more or less. }\end{array}$ \\
\hline & $\begin{array}{l}\text { I think so. I don't know how I got my answer } \\
\text { because I am confused. I don't know what } \\
\text { length to take. } \\
\text { Because on top of } Y \text { is nothing, no air, so } \\
\text { easy the gas to push. }\end{array}$ & $\begin{array}{l}\text { I understand the question. Looking at } \\
\text { the diagram, I took the } 15 \mathrm{~cm} \text { and minus } \\
\text { it with } 5 \mathrm{~cm} \text {. }\end{array}$ & $\begin{array}{l}\text { I understand the question. This part here is } \\
8 \mathrm{~cm} \text {, since that is the height difference } \\
\text { that should be the answer. } \\
\text { This part here raised up because no gas to } \\
\text { push (indicating the left level) and this part } \\
\text { is pushed. }\end{array}$ \\
\hline 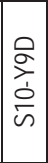 & $\begin{array}{l}\text { Maybe my answer is } 9 \text { plus } 9 \text { is } 18 \text { because } \\
\text { I was trying to find height difference. } \\
\text { Arah gas takan kebawah (pressure of gas } \\
\text { pushes the liquid down). } \\
\text { Sebalah (the next column) vacuum on top. }\end{array}$ & $\begin{array}{l}\text { I understand the question. } 5 \text { plus } 15 \text { is } \\
20 \text { then minus } 15 \text {. Can I change my } \\
\text { answer to } C \text {, I should do } 15 \text { minus } 5 \text {. }\end{array}$ & $\begin{array}{l}\text { I understand the question but I just got } \\
\text { confused with the height difference. } \\
\text { I should answer A. } \\
\text { Again more because the air is vacuum on } \\
\text { top the high level. }\end{array}$ \\
\hline
\end{tabular}

Additionally, two students (S9-Y9D and S10-Y9D, shown from the interview transcriptions in Table 4), on two separate interview occasions had referred to air pressure as vacuum. Another misconception was mistakenly taking the high liquid level of a manometer column as high pressure acting on that side and vice versa (S2-Y9A, shown also in Table 4). This misconception is caused by again failing to comprehend that air and also gas pressure can cause liquid levels to change.

Another confusion faced by the students was on identifying the height difference (S1-Y9A, S3-Y9A, S4-Y9B, S7Y9C and S8-Y9C, shown from the interview transcriptions in Table 5). There were five out of the eleven students interviewed who failed to grasp the true meaning of height difference of a manometer, this can be seen when the three manometer questions set for the four tests were labelled differently. Simple manipulation of the diagrams had caused a lot of confusions for the students. 
Table 5. Interview transcriptions for Items 1, 2 and 3 for the five Year 9 students

\begin{tabular}{|c|c|c|c|}
\hline No. & Item 1 & Item 2 & Item 3 \\
\hline $\begin{array}{l}\frac{\pi}{\sigma} \\
\frac{9}{1} \\
\dot{1}\end{array}$ & $\begin{array}{l}\text { I understand the question. I chose C because but } \\
\text { now I know it is wrong. I was confused because of } \\
\text { the line, so I just pick one height. } \\
\text { It is above atmospheric pressure because pressure } \\
\text { of gas is higher than atmospheric pressure. }\end{array}$ & $\begin{array}{l}\text { I understand the question. The } \\
\text { length of the right side minus the } \\
\text { left side because that is height } \\
\text { difference. }\end{array}$ & $\begin{array}{l}\text { I understand the question. Same as } \\
\text { before just take the height difference. } \\
\text { Since the right side is lower than right } \\
\text { side so more. }\end{array}$ \\
\hline $\begin{array}{l}\frac{\pi}{\sigma} \\
\text { ஸ் } \\
\tilde{\infty}\end{array}$ & $\begin{array}{l}\text { I understand the question. } \\
I \text { subtract level } Y \text { and } X \text { and I get the height } \\
\text { difference, } 9 \text { plus } 9 \text {. } \\
I \text { have to see where the tap is, if the tap level is } \\
\text { down so it is more. }\end{array}$ & $\begin{array}{l}\text { I understand the question. } \\
\text { It is because the level of the water } \\
\text { from the right you subtract it with } \\
\text { the level of the water from the left } \\
\text { then we get } 10 .\end{array}$ & $\begin{array}{l}\text { I understand the question. I got B } \\
\text { because I was confused, I thought I } \\
\text { have to add again like the last time but I } \\
\text { know it is still more than atmospheric } \\
\text { pressure by looking at the level under } \\
\text { the tap. }\end{array}$ \\
\hline $\begin{array}{l}m \\
\text { के } \\
\text { ஸे }\end{array}$ & $\begin{array}{l}\text { I understand the question. I chose my answer } 9 \mathrm{~cm} \\
\text { because I take the height from the dotted to } \mathrm{Y} \text {. I } \\
\text { know my answer is correct because that is the } \\
\text { height of the column from the top of } Y \text { to the dotted } \\
\text { level. (After explanation of height difference). I } \\
\text { should have plus } 9 \text { with } 9 \text {. They gave the height in } \\
\text { different measurement. I mean instead of giving the } \\
\text { real height they split the height. So I got confused. } \\
\text { It is above atmospheric pressure because level X } \\
\text { from the gas supplied is more lower than } Y \text {, } \\
\text { therefore more pressure is supplied to X. }\end{array}$ & $\begin{array}{l}\text { I understand the question. I found } \\
\text { the height from the base to the } \\
\text { level of atmospheric pressure } \\
\text { minus the level from the base to } \\
\text { the level of pressure applied from } \\
\text { the gas supply. }\end{array}$ & $\begin{array}{l}\text { I understand the question. I just take } \\
\text { the height difference. } \\
\text { The level from the gas supplied is more } \\
\text { lower than the height from the } \\
\text { atmospheric pressure. }\end{array}$ \\
\hline $\begin{array}{l}u \\
\text { o } \\
\text { n. } \\
\text { n }\end{array}$ & $\begin{array}{l}\text { I understand the question. I add the two heights } \\
\text { and that's how I get the answer. } \\
\text { The gas pushes the liquid. This end goes down } \\
\text { (indicating where the pressure of gas is acting) and } \\
\text { the other end goes up. }\end{array}$ & $\begin{array}{l}\text { I understand the question. It wants } \\
\text { the height difference so that we } \\
\text { could find the pressure. }\end{array}$ & $\begin{array}{l}\text { I understand the question. My answer } \\
\text { was } 12 \mathrm{~cm} \text { more than atmospheric } \\
\text { pressure. I added } 8 \mathrm{~cm} \text { with } 4 \mathrm{~cm} \text {. It } \\
\text { made me confuse because... the gas } \\
\text { pressure is higher that is why I add the } \\
\text { two numbers together. } \\
\text { It is more because I see the water level } \\
\text { going down on the gas supply side and } \\
\text { the other end rises up. }\end{array}$ \\
\hline 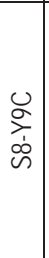 & $\begin{array}{l}\text { I understand the question. I add the two heights } \\
\text { and I got the answer. } \\
\text { It is because it rise the gas here on the left. So the } \\
\text { gas pushes the liquid and the water rises on the } \\
\text { other end. }\end{array}$ & $\begin{array}{l}\text { I understand the question. Height } \\
\text { difference is when I subtract the } \\
\text { height of the right with the left. }\end{array}$ & $\begin{array}{l}\text { I understand the question. I added both } \\
\text { numbers } \\
\text { I got confuse because... because the } \\
\text { question gave me two numbers on the } \\
\text { diagram so I thought I should do } \\
\text { something with the two numbers. } \\
\text { Because the gas is strong enough to } \\
\text { push the water down. }\end{array}$ \\
\hline
\end{tabular}

\section{Conclusions}

As seen from the results obtained, students did have misconceptions with regards to manometer reading, which were inconsistent with scientific views. This was consistent with the literature presented earlier by Zirbel (2006). The interviews done revealed that majority of the students had difficulties in fully understanding the true meaning of height difference of a manometer and simple labelling manipulation of manometer diagrams had resulted in many incorrect replies made by the students. It can also be concluded that the expression 'looks can be deceiving' is appropriate to describe the next misconception some students possessed, whereby they perceived that what they could not see was a solid basis to assume that nothing was there as highlighted in the study by Pathare and Pradhan (2011). In addition, identifying these misconceptions will indeed assist Physics secondary school teachers to confront the issues relating to the difficulty concerning the pressure concept.

From the interviews done in this study, we identified students' misconceptions of the pressure topic and lesson development was formulated to address them. However, further improvements should be made to ensure a full proof lesson development to decrease, if not totally eliminate, these alternate conceptions. Subsequently, it should be recommended to the curriculum department to include the alterations in the scheme of work so that the same problem is 
not repeated in the future.

Bearing in mind the experience obtained while conducting this research, similar future researches should be conducted with a larger sample size of Year 9 physics students. This is to verify if similar misconceptions are obtained and when employing the same interventions used in the lesson study, whether similar improvements are also achieved. Similar future studies can also be done in other science subjects with regards to pressure concepts and this is to observe if the same misconceptions also exist. If so then further investigations should be done to tackle the root of the cause, as the underlying reason could be the justification why related misconceptions occur in all the sciences.

\section{References}

Basca, B., \& Grotzer, T. A. (2001). Focusing on the nature of causality in a unit of pressure: How does it affect student understanding? Paper presented at the Annual Meeting of the American Educational Research Association (AERA), Seattle, WA.

Champagne, A. B., Gunstone, R. F., \& Klopfer, L. E. (1985). A reconceptualisation of the research into university academics' conceptions of teaching. Learning and Instruction. 7(3), 255-275.

Chi, M. (2000). Misunderstanding emergent processes as causal. Paper presented at the Annual Meeting of the American Educational Research Association (AERA), New Orleans.

Chinn, C. A., \& Brewer, W. F. (1993). The role of anomalous data in knowledge acquisition: A theoretical framework and implications for science instruction. Review of Educational Research, 63(1), 1-49.

Cil, E., \& Cepni, S. (2012). The effectiveness of the conceptual change approach, explicit reflective approach, and course book by the Ministry of Education on the views of the nature of science and conceptual change in light unit. Educational Sciences: Theory \& Practice, 12(2), 1107-1113.

Cosgrove, M., \& Osborne, R. (1985). Lesson frameworks for changing children's ideas: The Implications of Children's Science. Portsmouth, NH: Heinemann.

Damasio, A. R. (1994). Descartes' Error: Emotion, Reason and the Human Brain. Queensland: Quill.

Duit, R. (2003). Conceptual change approaches in science education. International Journal of Science Education, 25(6), 671-688.

Grotzer, T. A. (2004). Putting science within reach: Addressing patterns of thinking that limit science learning. Principal Leadership, 1721.

Hanuscin, D. (n.d.) Misconceptions in Science E328: Elementary Methods. Retrieved from http://www.indiana.edu/ w505a/studwork/ deborah/.

Hawker, S. (Ed). (2006). Little Oxford English Dictionary. Oxford University Press.

Hewson, P. W. (1992). Conceptual change in science teaching and teacher education. Paper presented at a meeting on "Research and Curriculum Development in Science Teaching," under the auspices of the National Center for Educational Research, Documentation, and Assessment, Ministry for Education and Science, Madrid, Spain, June 1992.

Hewson, M. G., \& Hewson, P. W. (2006). Effect of instruction using students' prior knowledge and conceptual change strategies on science learning. Journal of Research in Science Teaching, 20(8), 731-743.

Kariotoglou, P., \& Psillos, D. (1993). Pupil's pressure models and their implications for instruction. Research in Science and Technological Education, 11(1) 95-109.

LeDoux, J. (2003). The Synaptic Self: How our brains become who we are. Penguin Books.

Maier, S. (2004). Misconception Research and Piagetian Models of Intelligence. Paper presented at the Oklahoma Higher Education Teaching and Learning Conference.

Martin, R., Sexton, C., \& Gerlovich, J. (2002). Teaching Science for all Children: Methods for Constructing Understanding. Boston: Allyn and Bacon.

Mazur, E. (1997). Understanding or memorization: Are we teaching the right thing? In J. Wiley (Ed.), Conference on the Introductory Physics Course, pp. 113-124. John Wiley \& Sons, Inc., Chichester.

Nussbaum, J., \& Novick, N. (1982). Alternative frameworks, conceptual conflict, and accommodation: Toward a principled teaching strategy. Instructional Science, 11, 183-200.

Ornek, F., Robinson, W. R., \& Haugan, M. P. (2008). What makes physics difficult? International Journal of Environmental \& Science Education, 3(1), 30-34.

Pathare, S., \& Pradhan H. C. (2011). Students' alternative conceptions in pressure, heat and temperature. Physics Education, 21(3-4), 213-218.

Perkins, D. N., \& Grotzer, T. A. (2000). Models and moves: Focusing on dimensions of causal complexity to achieve deeper scientific understanding. Paper presented at the annual conference of the American Educational Research Association, New Orleans.

Posner, G. J., Strike, K. A., Hewson, P. W., \& Gertzog, W. A. (1982). Accommodation of a scientific conception: Toward a theory of conceptual change. Science Education, 66(2), 211-227.

Resnick, M. (1996). Beyond the centralized mindset. Journal of the Learning Sciences, 5(1), 1-22.

Sarwadi, H. R. H., \& Shahrill, M. (2014). Understanding students' mathematical errors and misconceptions: The case of year 11 repeating students. Mathematics Education Trends and Research, [Online] 1- 10.

Smith, C., Carey, S., \& Wiser, M. (1985). On differentiation: A case study of the concepts of size, weight, and density. Cognition, 21, 177-237. 
Smith, C., Maclin, D., Grosslight, L., \& Davis, H. (1997). Teaching for understanding: A study of students' preinstruction theories of matter and a comparison of the effectiveness of two approaches to teaching about matter and density. Cognition and Instruction, 15(30), 317- 393.

Smith, C., Snir, J., \& Grosslight, L. (1992). Using conceptual models to facilitate conceptual change: The case of weight-density differentiation. Cognition and Instruction, 9(3), 221-283.

Spitzer, M. (2002). The Net within the Web. NJ: Kluver.

Thompson, F. (2006). An exploration of common student misconceptions in science. International Education Journal, 7(4), 553-559.

Tyler, R. T. (1998). Children's conceptions of air pressure: exploring the nature of conceptual change. International Journal of Science Education, 20(8), 929-958.

Zirbel, E. L. (2006). Teaching to promote deep understanding and instigate conceptual change. Bulletin of the American Astronomical Society, 38, 1220. 